\title{
Commentary \\ On-Site Use of Plant Litter and Yard Waste as Mulch in Gardening and Landscaping Systems
}

\author{
Ilan Stavi ${ }^{1,2}$ \\ 1 Dead Sea and Arava Science Center, Yotvata 88820, Israel; istavi@adssc.org \\ 2 Eilat Campus, Ben-Gurion University of the Negev, Eilat 88100, Israel
}

Received: 28 July 2020; Accepted: 9 September 2020; Published: 11 September 2020

check for updates

\begin{abstract}
Plant litter, such as fallen leaves, branch trimmings, and other yard waste, plays important roles in both natural and man-made ecosystems. However, due to common aesthetic perceptions, land-owners or managers of many residential gardening and municipal landscaping systems consider these organic residues a burden, and therefore, clear them from the ground and dispose of them off-site. The removal of these organic resources increases the system's environmental footprint, decreases its sustainability, and negates the provision of important ecosystem services. At the same time, retaining these organic materials on-site could provide the system with substantial benefits. The most obvious effect is the ground surface shading, which decreases direct solar radiation to the soil, lowers soil temperature, lessens evaporation rates, decreases risk of soil salinization, and improves water-use efficiency. Ground surface mulching likewise prevents the raindrop splash impact, negates the formation of sealed mechanical crusts, improves water infiltrability, and reduces water runoff and soil erosion. Another benefit is the on-site decomposition of organic materials, which improves soil quality by elevating organic carbon concentration and contributing to nutrient cycling. Vegetation patches in such systems encompass "engineered fertility islands", which can be defined as highly productive, healthy, and functioning habitats. Further, over time, these systems require less maintenance. This management practice is crucial for tree- or shrub-dominated gardening and landscaping systems in drylands, where water availability is the major limiting factor of vegetation growth. However, global climate change, in which extended parts of the world experience increasing temperatures and decreasing precipitation rates, makes this practice relevant for other climatic regions as well.
\end{abstract}

Keywords: ecosystem functioning; irrigated vs. non-irrigated systems; leaf litter removal; pest control; soil food web; soil functions; soil salinity; weed control

\section{Introduction}

Gardening in private lots and landscaping in municipal lands are prevalent around the world for ornamental purposes, small-scale food production, or a combination of both. These systems sustain environmental quality and food security, and simultaneously, provide local communities with a wide range of ecosystem services [1,2]. In many of these lands, owners or managers consider the plant litter as a burden, and therefore routinely clear the ground surface, removing any fallen leaves, pruned branches, and other yard waste from gardening and landscaping systems [3-6]. This mode of operation is usually undertaken because of the commonly perceived aesthetic value of cleared ground surface. By doing so, an important resource is excluded from the garden system, and has to be replenished by other organic or synthetic materials. Meanwhile, on-site retention of locally shed plant litter and shredded or chopped branches sustains a range of ecosystem services and soil functions, such as plants' soil-water availability $[7,8]$, soil erosion control $[9,10]$, and soil organic carbon sequestration [11]. Nevertheless, specific studies that assess the potential benefits of this management 
practice in gardening and landscaping systems are relatively scant. Therefore, the objective of this short essay is to briefly highlight the advantages of this practice by demonstrating the most relevant geo-ecological impacts and economic implications. As shown in this study, the on-site use of plant litter and yard waste for mulching is relevant both for dryland and non-dryland regions.

\section{Benefits of On-Site Use of Plant Litter and Yard Waste as Mulch}

First and foremost, mulching the ground surface with plant litter-whether from native or introduced plants-regulates the soil-water dynamics. This impact is attributed to the shading of the ground surface, preventing solar radiation from directly hitting the soil, and lessening the heating of the soil's top horizons. As a result, soil-water evaporation rates decrease, thus increasing water availability for plant roots and improving the water-use efficiency of vegetation $[7,8]$. This chain of effects is particularly relevant for places where water availability is naturally limited, such as in drylands. It is further relevant for hot drylands (defined as BWh according to the Köppen climatic classification [12], which predominate the lower-middle subtropical zones, compared to cold drylands, defined as $B W k$ according to the aforementioned classification, which dominate higher latitudes), where the loss of soil-water through evaporation could be tremendous [13].

While some gardening and landscaping systems in non-dryland regions can be maintained with limited irrigation or even without irrigation, those in drylands must be routinely irrigated. Particularly in hot drylands, the loss of (irrigation) soil-water through evaporation is often coupled with soil salinization processes, usually named secondary salinity [14,15]. This process occurs as the capillary rise of water from the sub-soil to the surface soil dissolves salts and minerals from the soil matrix and deposits them in the surface soil horizons. Soil salinity can affect plant growth both physically and chemically. Regarding the physical effect, the increased osmotic pressure of the soil solution decreases the plants' ability to uptake soil-water, leading to water stress conditions for vegetation [15]. Drip irrigation with saline water can exacerbate this effect in dryland regions because saline water increases the deposition of salts and minerals on the ground surface and in the periphery of the 'wet bulbs' formed by drippers $[14,16]$. Occasional rainstorms dissolve the salts deposited on the ground surface and wash them down, exacerbating the osmotic pressure in the rhizosphere zone [17]. In terms of the chemical effect, the dissolved salts may cause the excessive accumulation of ions in the plant tissues, imposing toxicity risk for the plants [18,19]. Observations from the drylands of southern Israel, where many gardening and landscaping systems have received long-term drip irrigation with saline water (electrical conductivity (EC) ranging between $2.5-7.0 \mathrm{dS} \mathrm{m}^{-1}$ : personal communications), showing that the EC of soil solutions in non-mulched systems with moderate soil textures exceeds $32 \mathrm{dS} \mathrm{m}^{-1}$ (unpublished data obtained by the author; Figure 1), characterizing them as extremely saline [15]. However, mulched gardening and landscaping systems in the same physical settings have proved to have high effectiveness in preventing salinization, with the EC of soil solutions being generally lower than $4 \mathrm{dS} \mathrm{m}^{-1}$ (unpublished data obtained by the author; Figure 2), characterizing them as slightly to moderately saline [15].

In addition to the direct impacts, ground surface mulching by plant litter also indirectly affects soil-water dynamics. Specifically, preventing the raindrop impact (splash impact) negates the formation of sealed mechanical crusts on the ground surface, increases infiltration rates, and reduces the generation of overland flow of water. Alongside the conservation of water, this minimizes the loss of mineral and organic particles through inter-rill and rill erosional processes $[9,10]$.

Simultaneously, decomposing plant litter forms an (engineered) organic horizon (Ao horizon), which substantially increases the soil organic carbon concentration and improves the biophysiochemical quality of the soil's upper layer. This stimulates the soil's micro-, meso-, and macro-faunal biomass and activity, which, in turn, increase nutrient cycling and improve the soil's macro-aggregation processes and structure formation [11]. This increases the complexity of the soil food web, with the expected reduction of soil-borne diseases [20]. Over time, the improved soil conditions increase net primary productivity (NPP) and overall ecosystem functioning of the gardening or landscaping habitats [11]. As 
reported for natural ecosystems, the pedogenic and floral components of the system tend to strengthen each other through a web of positive feedbacks [7,21], generating the formation of "fertility islands" [22], in which pedogenesis and vegetation productivity continuously foster each other (Figure 3). Such a mechanism can be clearly demonstrated for spontaneously established vegetation, which acts as a trap for aeolian or alluvially transported plant litter (Figure 4). It is expected that over time, plant development and the litterfall trapped in these patches strengthen each other through positive feedbacks, forming highly productive and self-sustained vegetation patches $[7,23]$ with rich and diverse understory vegetation [24]. Practically, the on-site use of plat litter and yard waste as mulch in vegetation patches of gardening and landscaping systems, causes the formation of "engineered fertility islands". At the same time, the soil conditions in non-mulched vegetation patches, and particularly in those irrigated with saline water, may cause them unintentionally becoming "engineered sterility islands".

Regardless, ground surface mulching by plant litter is also expected to lower weed infestation, thus reducing the need for mechanical or chemical weed control [25]. However, it is acknowledged that mulching may also suppress germination of desirable herbaceous vegetation, lowering the system's complexity, stratification, and diversity.
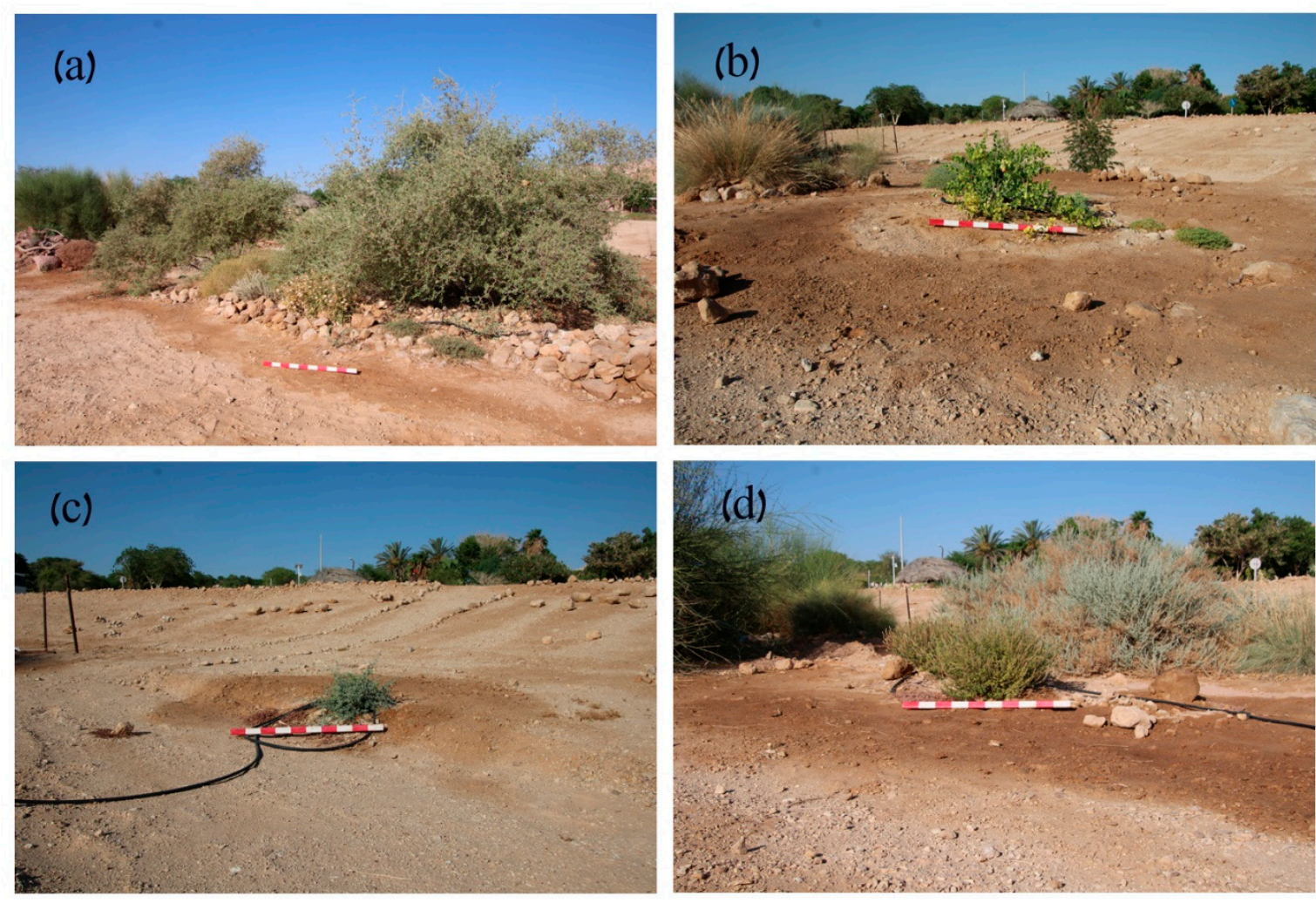

Figure 1. Soil salinization in planted vegetation patches of Ziziphus nummularia (Burm.f.) Wight and Arn. (with understory of several herbaceous plant species) (a), Capparis sinaica Veill (b), Nitraria retusa (Forssk.) Asch. (c), and Lavandula coronopifolia Poir (with Artemisia judaica L. in the background, and Leptadenia pyrotechnica (Forssk.) Decne. on the left) (d). The $1 \mathrm{~m}$ stick shows the scale. The ground surface's dark color and oily appearance indicate extreme salinization. These plants are either native or considered to be native to the hot Arava drylands of southern Israel. The pictures were taken by the author. 

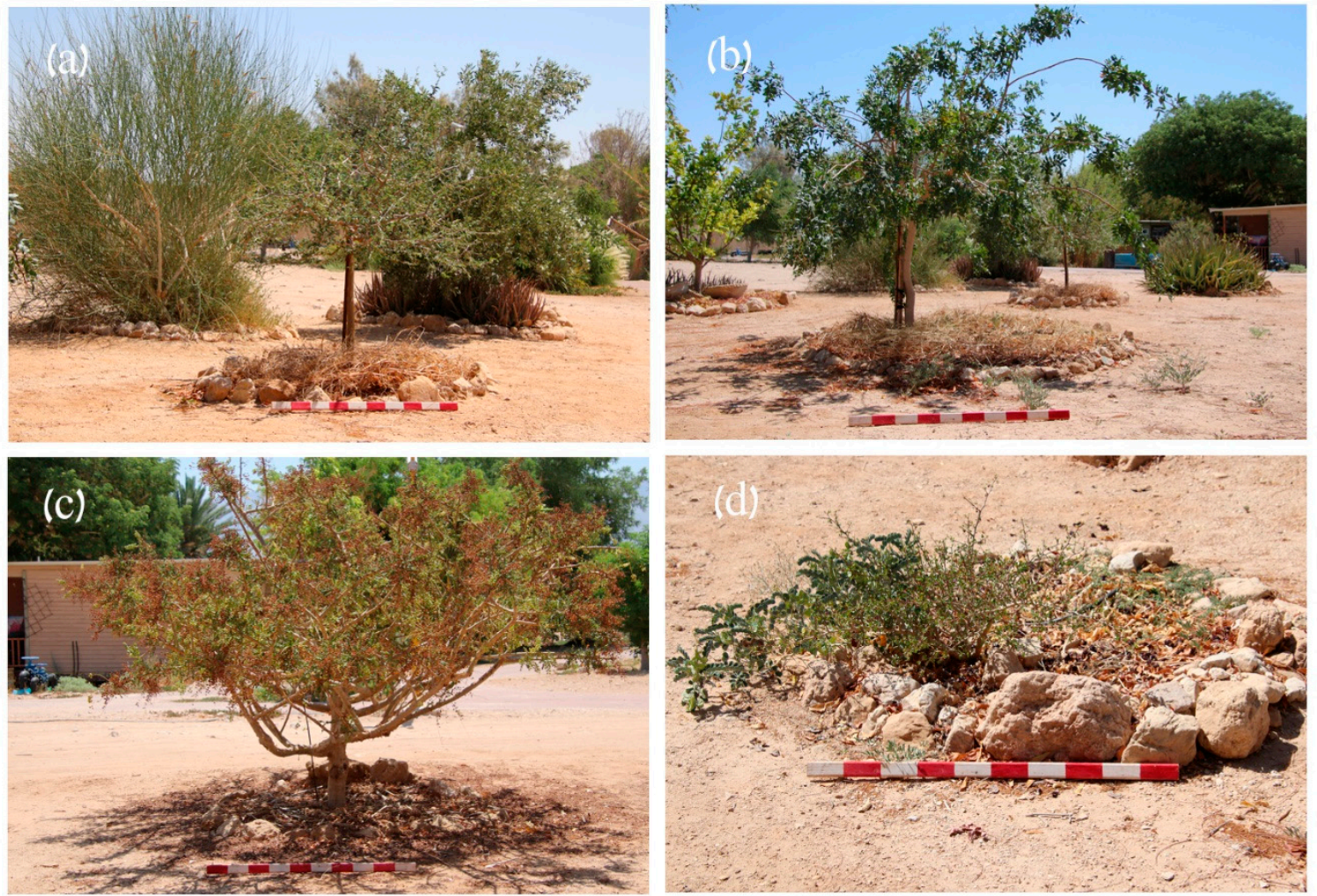

Figure 2. On-site use of plant litter and pruned branches as mulch reduces evaporation and negates soil salinization in planted vegetation patches of Senegalia laeta (R. Br. Ex Benth.) Seigler and Ebinger (a), Pistacia atlantica Desf. (b), Boswellia carterii Birdw. (c), and Commiphora myrrha (Nees) Engl. in the center and Senna italica Mill on the left (d). The $1 \mathrm{~m}$ stick shows the scale. These plants are either native or considered to be historically native in the hot Arava drylands of southern Israel. The pictures were taken by the author.

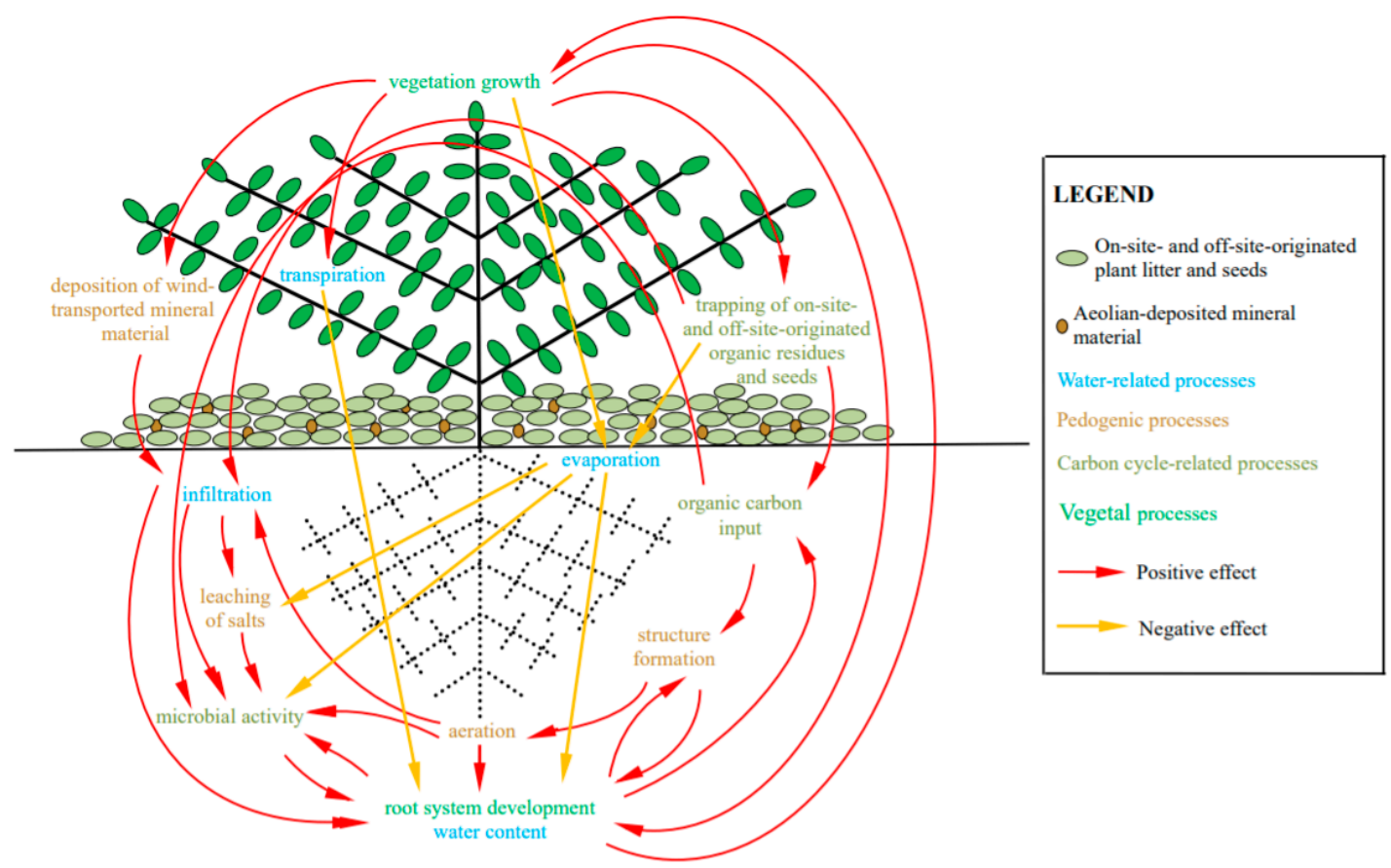

Figure 3. Schematic illustration of geo-ecological processes taking place in well-functioning vegetation patches. Note: Modified from Stavi et al. [34]. 


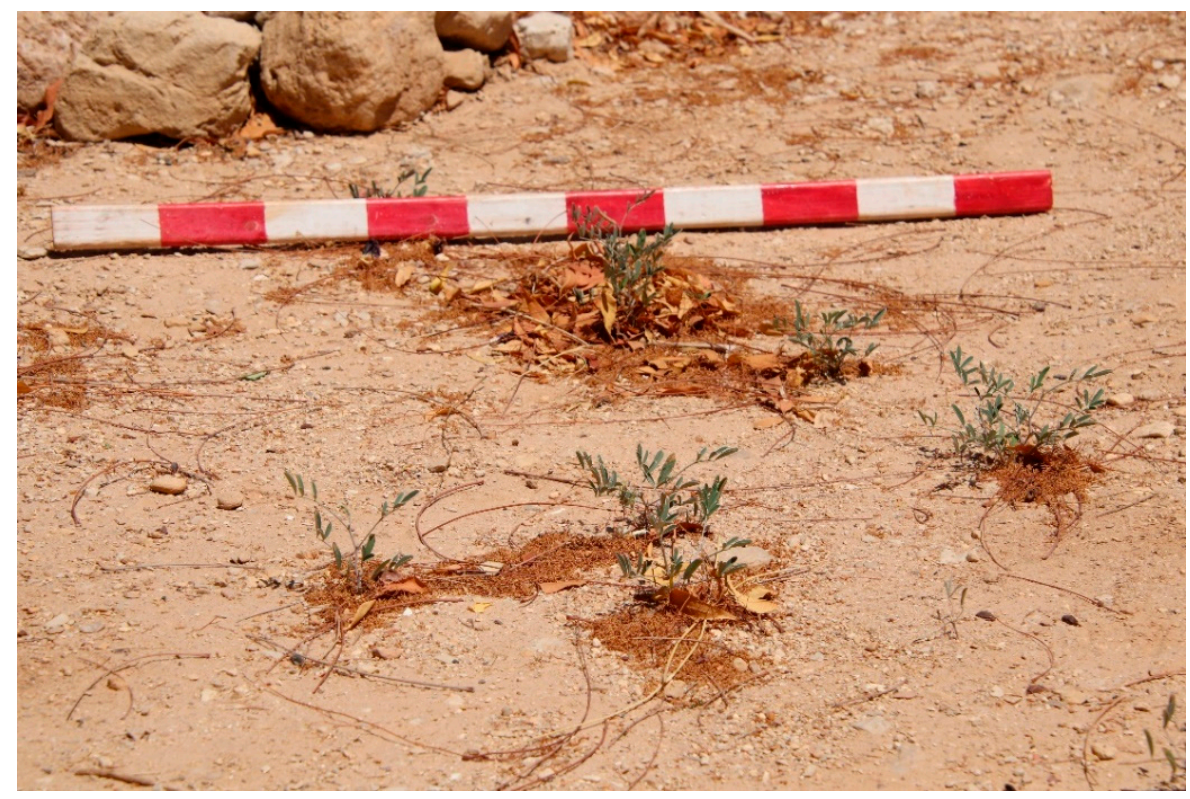

Figure 4. Trapping of off-site, wind-transported organic debris by the canopy of spontaneously sprouted native Tephrosia apollinea (Delile) Link plants. The $1 \mathrm{~m}$ stick shows the scale. The picture was taken by the author in the Arava drylands of southern Israel.

\section{Limitations and Implications}

Careful attention should be paid when planting vegetation species with potentially allelopathic properties. For example, pine (Pinus spp.) tree needles are known to have a strong allelopathic impact, adversely affecting the germination of understory vegetation [26]. A similar allelopathic effect of plant litterfall was also reported for many other tree and shrub genera, such as eucalypt (Eucalyptus: [27]), poplar (Populus: [28]), tamarisk (Tamarix: [29]), and lantana (Lantana: [30]). Furthermore, invasive tree and shrub species with allelochemicals or other allelopathic mechanisms should be avoided [31]. In addition to the on-site detrimental impacts in the gardening or landscaping system, these species may also harm the surrounding off-site ecosystems, potentially adversely affecting the native plant community's structure, richness, and diversity [32].

Overall, litterfall, pruned branches, and other yard waste should not be considered as a burden, but rather as a high-valued resource. Judicious on-site use of these materials for mulching is an environmentally friendly practice that is expected to reduce the environmental footprint of residential gardening and municipal landscaping systems. Furthermore, this management practice is expected to decrease maintenance costs by reducing expenses for irrigation, herbicides, pesticides, and labor. It is also expected to reduce additional costs that would have otherwise been imposed on land managers, such as transportation to disposal sites and payment of fees for landfill services. Despite these advantages, it is often difficult to retain excess organic debris on-site. This necessitates the transfer of these materials to other sites, where they can be used as mulch or converted to other products such as compost, feedstock for bioenergy, etc.

The judicious on-site use of plant litter is most important in drylands, where rainfalls are scarce, water availability is naturally limited, and the need to maximize water-use efficiency in gardening and landscaping systems is evident. However, climatic changes, including forecasted elevated temperatures and increasing frequency and magnitude of long-term droughts in non-dryland regions, as well as the expansion of global dryland areas (e.g., [13,33]), make this management practice relevant for other climatic regions as well. Therefore, this practice is pertinent not only for the resource-scarce, developing, and emerging countries of the 'Global South', but also for 'northern', wealthy, and developed countries. However, empiric experiments are needed in order to assess the actual effects of on-site retention of plant litter, tree trimmings, and other yard waste on ecosystem services in residential gardening and 
municipal landscaping systems in a range of climatic regions. Of these ecosystem services, assessments of the specific impacts on water-use efficiency, soil salinization prevention, soil erosion control, soil organic carbon sequestration, soil food web complexity, ecosystem health, and NPP are particularly relevant. Regardless, extension and demonstration projects may cause a desirable change in the public's aesthetic perceptions towards valuing the on-site use of plant litter and yard waste for mulching in gardening and landscaping systems.

Funding: This research received no external funding.

Acknowledgments: General support for this study was provided by the Israel Ministry of Science and Technology.

Conflicts of Interest: The author declares no conflict of interest.

\section{References}

1. Çelik, F. The importance of edible landscape in the cities. Turk. J. Agric. Food Sci. Technol. 2017, 5, 118-124. [CrossRef]

2. Mancebo, F. Gardening the city: Addressing sustainability and adapting to global warming through urban agriculture. Environments 2018, 5, 38. [CrossRef]

3. Bradley, L. Plants for Poolside Landscapes; Publication AZ1058 8/98; The University of Arizona Cooperative Extension: Phoenix, AZ, USA, 1998; Available online: https:/cals.arizona.edu/extension/ornamentalhort/ landscapemgmt/plantmaterial/poolsideplants.pdf (accessed on 25 July 2020).

4. Schutzki, R.E. A Guide for the Selection and Use of Plants in the Landscape; Extension Bulletin E-2941; Michigan State University Extension: East Lansing, MI, USA, 2005; Available online: https://www.canr.msu.edu/uploads/resources/pdfs/a_guide_for_the_selection_and_use_of_plants_ in_the_landscape_(e2941).pdf (accessed on 25 July 2020).

5. Centre for Urban Greenery \& Ecology. Sustainable Landscape; Centre for Urban Greenery \& Ecology: Singapore, 2015. Available online: https://www.nparks.gov.sg///media/cuge/ebook/sustainable-landscape/sustainablelandscape.pdf (accessed on 25 July 2020).

6. Aryani, N.P.; Fibriana, F.; Anwar, A.F.; Ummayah, F.F.D.; Alighiri, D.; Harjono; Masturi. Characterization of mahogany leaf litter (Swietenia macrophylla King) as a raw material of decay resistance biocomposite. $J$. Phys. Conf. Ser. 2019, 1321, 022022. [CrossRef]

7. Stavi, I.; Lavee, H.; Ungar, E.D.; Sarah, P. Eco-geomorphic feedbacks in semi-arid rangelands: A review. Pedosphere 2009, 19, 217-229. [CrossRef]

8. Hatfield, J.L.; Dold, C. Water-use efficiency: Advances and challenges in a changing climate. Front. Plant Sci. 2019, 10, 103. [CrossRef]

9. Gholami, L.; Sadeghi, S.H.; Homaee, M. Straw mulching effect on splash erosion, runoff, and sediment yield from eroded plots. Soil Sci. Soc. Am. J. 2013, 77, 268-278. [CrossRef]

10. Shi, Z.H.; Yue, B.J.; Wang, L.; Fang, N.F.; Wang, D.; Wu, F.Z. Effects of mulch cover rate on interrill erosion processes and the size selectivity of eroded sediment on steep slopes. Soil Sci. Soc. Am. J. 2013, 77, 257-267. [CrossRef]

11. Tresch, S.; Frey, D.; Le Bayon, R.C.; Zanetta, A.; Rasche, F.; Fliessbach, A.; Moretti, M. Litter decomposition driven by soil fauna, plant diversity and soil management in urban gardens. Sci. Total Environ. 2019, 658, 1614-1629. [CrossRef]

12. Kottek, M.; Greiser, J.; Beck, C.; Rudolf, B.; Rubel, F. World map of the Köppen-Geiger climate classification updated. Meteorol. Z. 2006, 15, 259-263. [CrossRef]

13. Huang, J.; Li, Y.; Fu, C.; Chen, F.; Fu, Q.; Dai, A.; Shinoda, M.; Ma, Z.; Guo, W.; Li, Z.; et al. Dryland climate change: Recent progress and challenges. Rev. Geophys. 2017, 55, 719-778. [CrossRef]

14. Wang, R.; Wan, S.; Kang, Y.; Dou, C. Assessment of secondary soil salinity prevention and economic benefit under different drip line placement and irrigation regime in northwest China. Agric. Water Manag. 2014, 131, 41-49. [CrossRef]

15. McFarlane, D.J.; George, R.J.; Barrett-Lennard, E.G.; Gilfedder, M. Salinity in dryland agricultural systems: Challenges and opportunities. In Innovations in Dryland Agriculture; Farooq, M., Siddique, K.H.M., Eds.; Springer: Berlin, Germany, 2016; pp. 521-547. 
16. Selim, T.; Bouksila, F.; Berndtsson, R.; Persson, M. Soil water and salinity distribution under different treatments of drip irrigation. Soil Sci. Soc. Am. J. 2013, 77, 1144-1156. [CrossRef]

17. Tripler, E.; Grinwald, T.; Maduel, A. The Effect of Rainfalls on Vegetable Crops Irrigated with Saline Water; A report submitted to the Ministry of Agriculture and Rural Development; Southern Arava Research and Development Center: Yotvata, Israel, 2016; Available online: http://agri.arava.co.il/wp-content/uploads/f6_\%D7\%A4\%D7\%9C\%D7\%A4\%D7\%9C-\%D7\%94\%D7\% 93\%D7\%9E\%D7\%99\%D7\%AA-\%D7\%92\%D7\%A9\%D7\%9D-1516.pdf (accessed on 25 July 2020). (in Hebrew)

18. Minhas, P.S. Saline water management for irrigation in India. Agric. Water Manag. 1996, 30, 1-24. [CrossRef]

19. Deb, S.K.; Sharma, P.; Shukla, M.K.; Sammia, T.W.; Ashigh, J. Drip-irrigated seedlings response to irrigation water salinity. Hortscience 2013, 48, 1548-1555. [CrossRef]

20. Abawi, G.S.; Widmer, T.L. Impact of soil health management practices on soilborne pathogens, nematodes and root diseases of vegetable crops. Appl. Soil Ecol. 2000, 15, 37-47. [CrossRef]

21. Veen, G.F.; Fry, E.L.; ten Hooven, F.C.; Kardol, P.; Morriën, E.; De Long, J.R. The role of plant litter in driving plant-soil feedbacks. Front. Environ. Sci. 2019, 7, 168. [CrossRef]

22. Garner, W.; Steinberger, Y. A proposed mechanism for the formation of "fertile islands" in the desert ecosystem. J. Arid Environ. 1989, 16, 257-262. [CrossRef]

23. Bargali, S.S.; Padalia, K.; Bargali, K. Effects of tree fostering on soil health and microbial biomass under different land use systems in the Central Himalayas. Land Degrad. Dev. 2019, 30, 1984-1998. [CrossRef]

24. Yelenik, S.G. Linking dominant Hawaiian tree species to understory development in recovering pastures via impacts on soils and litter. Restor. Ecol. 2017, 25, 42-52. [CrossRef]

25. Petrikovszki, R.; Zalai, M.; Bogdányi, F.T.; Tóth, F. The effect of organic mulching and irrigation on the weed species composition and the soil weed seed bank of tomato. Plants 2020, 9, 66. [CrossRef]

26. Kimura, F.; Sato, M.; Kato-Noguchi, H. Allelopathy of pine litter: Delivery of allelopathic substances into forest floor. J. Plant Biol. 2015, 58, 61-67. [CrossRef]

27. Zhang, C.; Fu, S. Allelopathic effects of eucalyptus and the establishment of mixed stands of eucalyptus and native species. Forest Ecol. Manag. 2009, 258, 1391-1396. [CrossRef]

28. Sher, Z.; Hussain, F.; Ahmad, B.; Wahab, M. Allelopathic potential of Populus euphratica Olivier. Pak. J. Bot. 2011, 43, 1899-1903.

29. Katz, O.; Stavi, I. Hierarchical effects of Tamarix aphylla afforestation in a sand dune environment on vegetation structure and plant diversity. Forest Sci. 2020, in press. [CrossRef]

30. Negi, G.C.S.; Sharma, S.; Vishvakarma, S.C.R.; Samant, S.S.; Maikhuri, R.K.; Prasad, R.C.; Palni, L.M.S. Ecology and use of Lantana camara in India. Bot. Rev. 2019, 85, 109-130. [CrossRef]

31. Yadav, V.; Singh, N.B.; Singh, H.; Singh, A.; Hussain, I. Allelopathic invasion of alien plant species in India and their management strategies: A review. Trop. Plant Res. 2016, 3, 87-101.

32. Niemiera, A.X.; Von Holle, B. Invasive plant species and the ornamental horticulture industry. In Management of Invasive Weeds; Inderjit, Ed.; Springer: Berlin, Germany, 2009; pp. 167-187.

33. Cook, B.I.; Smerdon, J.E.; Seager, R.; Coats, S. Global warming and 21st century drying. Clim. Dyn. 2014, 43, 2607-2627. [CrossRef]

34. Stavi, I.; Siegal, Z.; Drori, B.; Hyams, E.; Shafir, A.; Kamiski, Y.; Al-Ashhab, A.; Dorman, M.; Tsoar, A. Single session of chiseling tillage for soil and vegetation restoration in severely degraded shrublands. Water 2018, 10, 755. [CrossRef]

(C) 2020 by the author. Licensee MDPI, Basel, Switzerland. This article is an open access article distributed under the terms and conditions of the Creative Commons Attribution (CC BY) license (http://creativecommons.org/licenses/by/4.0/). 